\title{
EFEKTIVITAS PENGGUNAAN SPEECH TRAINER PADA KASUS GANGGUAN PENDENGARAN STUDI KASUS DI YPAC SURAKARTA
}

\author{
Gunawan*1, Anisyah Dewi Syah Fitri ${ }^{2}$ \\ Poltekkes Kemenkes Surakarta Jurusan Terapi Wicara
}

\begin{abstract}
Background: Hearing loss is the difficulty of someone to hear sounds from mild to severe degrees, so that they experience obstacles in understanding other people's speech through their own hearing or someone who has lost the ability to hear so that they cannot process language information through hearing with or without hearing aids (Travis, 1978).Based on the Results of Basic Health Research conducted by the Indonesian Ministry of Health in 2013 (Riskesdas 2013) presents significant information in terms of the prevalence of disability in children. The prevalence of blind people is $0.17 \%$, speech impaired $0.14 \%$, down syndrome $0.13 \%$, physical impairment 0.08 , hearing impaired $0.07 \%$ and disability caused by trauma and accidents $0.53 \%$. In children aged 24 - 59 months found $0.14 \%$ of children who are speechless from the overall data of children with disabilities.Speech therapy to handle cases of hearing loss, with Speech Trainer aids, especially articulations.The main purpose of providing effective information and benefits of speech trainer aids for speech therapy cases of dysaudia aged 3-6 years specifically in the pronunciation of consonant / $r$ / Late articulation.Providing information to the Speech Therapist, one of the procedures in the use of speech trainer therapy aids, especially in the case of dysaudia who do not use Google implants.Providing information and understanding to parents about the problem of a child's condition that does not use sophisticated Google implants, can be treated with speech trainer. Because Koglea implants are expensive. Methods: This research uses survey method, aims to find information that will be used to solve problems and not to test hypotheses. The instruments in this study were consonants / $\mathrm{r} /$ followed by vocal sounds [/ a /, / $\mathrm{i} / \mathrm{/} / \mathrm{l} / \mathrm{e} / \mathrm{l} / \mathrm{e} /$ and / o /] the final position in the form of words as follows: Snake, Comb, Egg, Suitcase, Bucket, Tail. With the help of pictures. and Therapeutic Tools used in intervening in Children, namely: Speech Trainer and Consonant / $r$ /Articulation Card and Mirror. Results: Based on the results of this study, it can be concluded that from the study land surveyed as many as 4 (four) children with hearing loss in YPAC. Conclusion: Speech Trainer did not show any influence at the time of T1 to T4, there was an influence at the time of T5 that is indicated in the word Comb there were 3 subjects (75.0\%), eggs had 3 subjects (75.0\%), Buckets had 1 Subject ( 25.0\%), and tails there were 2 subjects (50.0\%), whereas in the word snake, and luggage did not show any successful pronunciation.The effectiveness of using Speech Trainer lies in the pronunciation of the consonant / $r$ / on the word comb and egg on T5 $(p=0.010)$.
\end{abstract}

Keywords: Effectiveness of using speech trainer especially consonant, Articulation in Hearing Loss Cases aged 3-6 case study in YPAC Surakarta 


\section{PENDAHULUAN}

Manusia adalah makhluk sosial yang tidak dapat hidup sendiri, sehingga membutuhkan interaksi kepada manusia atau lawan bicara agar dapat melangsungkan hidupnya. Manusia hidup bersama-sama dengan orang lain di lingkungannya, maka membutuhkan alat komunikasi (ujaran, tulis, isyarat) yang berhubungan dengan proses berfikir dan sekaligus lambang sosial umat manusia dalam berinteraksi dengan sesama di lingkungannya.

Noam Chomsky, yang terkenal dengan teori Transformasi Generatifnya, adalah salah seorang yang berpendapat bahwa berbahasa merupakan kegiatan asasi manusia. Karena manusia pada fitrahnya atau secara genetis, dilengkapi dengan kemampuan berbahasa. Kemampuan itu ada secara potensial dalam otak manusia. Chomsky menyebutkan Language Acquasition Device (LAD). (Revolusi IQ/EQ/SQ Antara Neurosains dan Al-Quran, Dr. H. Taufik Pasiak 2002).

Ernst Cassirer, sebagai sistem simbol, bahasa adalah mata rantai ketiga yang hanya dapat ditemukan pada manusia, sehingga tepatlah manusia disebut sebagai animal symbolicum, makhluk pembuat dan penafsir simbol. Semua terangkum dalam sebuah kata : "Berpikir". (Revolusi IQ/EQ/SQ Antara Neurosains dan Al-Quran, Dr. H. Taufik Pasiak 2002).

Di dunia, menurut perkiraan WHO Di dunia, menurut perkiraan WHO pada tahun 2010 terdapat 278 juta orang menderita gangguan pendengaran, 75 140 juta diantaranya terdapat di Asia Tenggara. Sedangkan pada bayi, terdapat $0,10,2 \%$ menderita tuli sejak lahir atau setiap 1.000 kelahiran hidup terdapat 12 bayi yang menderita tuli. Di Indonesia, gangguan pendengaran dan ketulian saat ini masih merupakan satu masalah yang dihadapi masyarakat.

Berdasarkan hasil Survei Nasional

Kesehatan Indera Penglihatan dan Pendengaran di 7 provinsi tahun 19931996, prevalensi ketulian $0,4 \%$ dan gangguan pendengaran $16,8 \%$. Penyebabnya, infeksi telinga tengah $(3,1 \%)$ presbikusis $(2,6 \%)$, tuli akibat obat ototoksik $(0,3 \%)$, tuli sejak lahir/kongenital $(0,1 \%)$ dan tuli akibat pemaparan bising.

WHO Multi Center Study 1998 Indonesia termasuk 4 negara di Asia Tenggara dengan prevalensi ketulian yang cukup tinggi $(4,6 \%), 3$ negara lain Sri Langka $(8,8 \%)$, Myamar $(8,4 \%)$ dan India $(6,3 \%)$.

Hasil Survey Indera Pengelihatan dan Pendengaran 1994-1996 di laksanakan pada 7 propinsi di Indonesia Prevalensi Ketulian 0,4 \%, Tuli mendadak (0,2\%), Tuna Rungu (0,1\%). (Kepmenkes RI No 879/ Menkes/SK/XI/2006 tentang Rencana Strategi Nasional Penanggulangan Gangguan Pendengaran dan Ketulian Mancapai Sound Hearing 2030.)

Berdasarkan Hasil Riset Kesehatan Dasar yang dilakukan oleh Kementerian Kesehatan RI pada tahun 2013 (Riskesdas 2013) menyajikan informasi yang signifikan dalam hal prevalensi kecacatan pada anak. Prevalensi tuna netra 0,17 \%, tuna wicara $0,14 \%$, down syndrome 0,13 $\%$, tuna daksa 0,08 , tuna rungu $\mathbf{0 , 0 7} \%$ dan kecacatan yang diakibatkan oleh trauma dan kecelakaan 0,53\%. Pada anak usia 24 - 59 bulan didapatkan $0,14 \%$ anak tuna wicara dari keseluruhan data anak cacat. 
Dalam penelitian ini peneliti akan melakukan terapi wicara untuk menangani kasus gangguan pendengaran, peneliti membatasi terapi. Alat bantu terapi yang peneliti gunakan adalah pemakaian alat bantu terapi Speech Trainer untuk terapi wicara khususnya artikulasi Konsonan /r/ pada anak Disaudia karena Gangguan Pendengaran di YPAC Surakarta. Banyaknya kasus gangguan pendengaran peneliti tertarik untuk mengambil judul “ Efektifitas Penggunaan Speech Trainer khususnya artikulasi Konsonan /r/ pada Kasus Gangguan Pendengaran studi kasus di YPAC Surakarta".

\section{METODE PENELITIAN}

\section{Desain Penelitian}

Penelitian ini menggunakan metode Survei, bertujuan untuk mencari informasi yang akan digunakan untuk memecahkan masalah dan bukan untuk menguji hipotesis.

\section{Populasi penelitian}

a. Populasi

Populasi penelitian ini adalah seluruh anak Disaudia di YPAC.

b. Sampel

Dalam penelitian ini penentuan sampel menggunakan teknik purposive sampling yang artinya ditentukan dengan mempertimbangkan tujuan penelitian berdasarkan kriteriakriteria yang ditentukan terlebih dahulu. Adapun kriteria-kriteria yang diberlakukan untuk sampel penelitian ini di antaranya:

1) Anak Disaudia Laki-laki dan Perempuan
2) Berusia 3-6 tahun

3) Tidak Memakai Koglea Implan Dalam penelitian ini peneliti menentukan sampel penelitian sebanyak 4 siswa. laki-laki 2 siswa dan perempuan 2 siswa.

\section{Fonem}

Yang di tes dalam penelitian artikulasi adalah fonem-fonem dalam fonologi bahasa Indonesia perposisi awal, tengah dan akhir pada seluruh kata, meliputi vokal [/a/, /i/, /u/, /e/, /o/, /e/], konsonan [/p/, /b/, /m/, /w/, /f/, /v/, /k/, /ng/, /h/, /s/, $/ \mathrm{t} /, / \mathrm{n} /, / \mathrm{l} /, / \mathrm{r} /, / \mathrm{g} /, / \mathrm{c} /, / \mathrm{x} /, / \mathrm{j} /, / \mathrm{y} /$, /ny/, /y/, /q/] dan Diftong [/ai/, /au/, /oi/].

\section{Estimasi proporsi}

Siswa SD kelas rendah yaitu kelas 1 usia 6 sampai 7 tahun menurut jenis kelamin dan penyimpangan artikulasi fonem-fonem bahasa Indonesia.

\section{Intrumen Penelitian}

a. Instrumen dalam penelitian ini adalah berupa Konsonan $/ \mathrm{r} /$ yang diikuti bunyi vocal [ /a/,/i/,/u/e/,/e/ dan /o/ ] posisi akhir dalam bentuk kata sebagai berikut : Ular, Sisir, Telur, Koper, Ember, Ekor dengan bantuan gambar .

b. Alat Terapi Speech Trainer dan Kartu artikulasi Konsonan /r/ serta Cermin.

\section{Teknik Analisa Data}

Pengolahan Data :

a. Analisis Data

Durasi waktu terapi Durasi atau lama waktu terapi yang dilakukan selama 30 menit setiap pertemuan. Seminggu 2 kali dalam waktu 5 kali terapi

HASIL PENELITIAN

Tabel 1. Perbedaan Keberhasilan Pengucapan Konsonan /r/ yang Diikuti Bunyi Vocal [ /a/,/i/,/u/e/,/e/ dan /o/ ] Posisi Akhir Dalam Bentuk Kata Sebagai Berikut : Ular, Sisir, 
Telur, Koper, Ember, Ekor Dilakukan Dengan Uji Chi Square (Uji Beda K tidak Berpasangan dengan Data

\begin{tabular}{ccccccc}
\hline \multicolumn{7}{c}{ Pengucapan } \\
\hline $\begin{array}{c}\text { Ular } \\
(\mathbf{n}=4)\end{array}$ & $\begin{array}{c}\text { Sisir } \\
(\mathbf{n}=\mathbf{4})\end{array}$ & $\begin{array}{c}\text { Telor } \\
(\mathbf{n}=\mathbf{4})\end{array}$ & $\begin{array}{c}\text { Koper } \\
(\mathbf{n = 4})\end{array}$ & $\begin{array}{c}\text { Ember } \\
(\mathbf{n}=\mathbf{4})\end{array}$ & $\begin{array}{c}\text { Ekor } \\
(\mathbf{n}=\mathbf{4})\end{array}$ & P-value \\
\hline 0 & 0 & 0 & 0 & 0 & 0 & - \\
0 & 0 & 0 & 0 & 0 & 0 & - \\
0 & 0 & 0 & 0 & 0 & 0 & - \\
0 & 0 & 0 & 0 & 0 & 0 & - \\
0 & 0 & 0 & 0 & 0 & 0 & - \\
0 & 3 & 3 & 0 & 1 & 2 & 0,072 \\
\hline
\end{tabular}

Hasil menunjukan pada table 1 sedangkan pada kata ular, dan koper tidak penggunaan Speech Trainer tidak menunjukan adanya keberhasilan menunjukan adanya pengaruh pada waktu pengucapan. Hasil uji statistik T1 sampai dengan T4, mulai ada pengaruh mendapatkan nilai $\mathrm{p}=0,072(\mathrm{p}>0,05)$ yang pada waktu T5 yaitu ditunjukan pada kata berarti tidak ada perbedaan yang Sisir ada 3 subyek $(75,0 \%)$, telor ada 3 signifikan keberhasilan pengucapan subyek $(75,0 \%)$, Ember ada 1 Subyek berdasarkan dengan menggunakan Speech $(25,0 \%)$, dan ekor ada 2 subyek $(50,0 \%)$, Trainer.

Tabel 2. Keberhasilan Pengucapan Konsonan /r/ pada Kata Ular dengan Menggunakan Speech Trainer Dibandingkan Antar Waktu Pengambilan Data Penelitian (sebelum, T1, T2, T3, T4, dan T5) Menggunakan Uji Friedman Test (Uji K Berpasangan dengan Data Kategorik)

\begin{tabular}{lcrrrrrr}
\hline Pengucapan & Sebelum & TI & T2 & T3 & T4 & T5 & p-value \\
\hline Ular & 0 & 0 & 0 & 0 & 0 & 0 & - \\
\hline Diketahui bahwa dari & T1 sampai & penggunaan Speech Trainer tidak efektif \\
dengan T5 tidak ada subyek penelitian & pada kata ular. Nilai p-value tidak \\
yang berhasil mengucapkan Konsonan /r/ & $\begin{array}{l}\text { terdefinisi karena tidak ada variansi data } \\
\text { pada kata ular. dengan demikian }\end{array}$ & dalam penelitian.
\end{tabular}

Tabel 3. Keberhasilan Pengucapan Konsonan /r/ Pada Kata Sisir Dengan Menggunakan Speech Trainer Dibandingkan Antar Waktu Pengambilan Data Penelitian (sebelum, T1, T2, T3, T4, dan T5) Menggunakan Uji Friedman Test (Uji K Berpasangan Dengan Data Kategorik)

\begin{tabular}{cccccccc}
\hline Pengucapan & Sebelum & TI & T2 & T3 & T4 & T5 & p-value \\
\hline Sisir & 0 & 0 & 0 & 0 & 0 & 3 & 0,010 \\
\hline Diketahui bahwa dari bahwa dari T1 & pada T5 yaitu ada 3 subyek $(75,0 \%)$ yang \\
sampai dengan T4 tidak ada subyek & berhasil mengucapkan Konsonan $/ \mathrm{r} / \mathrm{pada}$ \\
penelitian yang berhasil mengucapkan & kata sisir. hasil uji statistik didapatkan \\
Konsonan /r/ pada kata sisir, dampak & nilai p-value $=0,010 \quad(\mathrm{p}<0,05)$ yamg \\
penggunaan Speech Trainer dirasakan & berarti bahwa terdapat perbedaan yang
\end{tabular}


signifikan pengucapan Konsonan /r/ pada kata sisir dengan menggunakan Speech Trainer dibandingkan antar waktu pengambilan data penelitian (sebelum, T1,
T2, T3, T4, dan T5) dengan demikian penggunaan Speech Trainer efektif pada pengucapan Konsonan /r/ pada kata sisir pada waktu T5.

Tabel 4. Keberhasilan Pengucapan Konsonan /r/ Pada Kata Telor dengan Menggunakan Speech Trainer Dibandingkan Antar Waktu Pengambilan Data Penelitian ( Sebelum, T1, T2, T3, T4, dan T5 ) Menggunakan Uji Friedman Test ( Uji K Berpasangan Dengan Data Kategorik )

\begin{tabular}{lccccccc}
\hline Pengucapan & Sebelum & TI & T2 & T3 & T4 & T5 & p-value \\
\hline Telor & 0 & 0 & 0 & 0 & 0 & 3 & 0,010 \\
\hline
\end{tabular}

Diketahui bahwa dari T1 sampai dengan T4 tidak ada subyek penelitian yang berhasil mengucapkan Konsonan /r/ pada kata telor, dampak penggunaan Speech Trainer dirasakan pada T5 yaitu ada 3 subyek $(75,0 \%)$ yang berhasil mengucapkan Konsonan /r/ pada kata telor. hasil uji statistik didapatkan nilai pvalue $=0,010 \quad(\mathrm{p}<0,05)$ yamg berarti bahwa terdapat perbedaan yang signifikan pengucapan Konsonan /r/ pada kata telor dengan menggunakan Speech Trainer dibandingkan antar waktu pengambilan data penelitian (sebelum, T1, T2, T3, T4, dan T5). Dengan demikian penggunaan Speech Trainer efektif pada pengucapan Konsonan /r/ pada kata telor pada waktu T5.

Tabel 5. Keberhasilan Pengucapan Konsonan /r/ Pada Kata Koper dengan Menggunakan Speech Trainer Dibandingkan Antar Waktu Pengambilan Data Penelitian (Sebelum, T1, T2, T3, T4, dan T5) Menggunakan Uji Friedman Test (Uji K Berpasangan Dengan Data Kategorik)

\begin{tabular}{lccccccc}
\hline Pengucapan & Sebelum & TI & T2 & T3 & T4 & T5 & p-value \\
\hline Koper & 0 & 0 & 0 & 0 & 0 & 0 & - \\
\hline Diketahui & bahwa dari waktu & T1 & demikian penggunaan Speech Trainer \\
sampai dengan & T5 tidak ada subyek & tidak efektif pada kata telor. Nilai p-value \\
penelitian yang berhasil mengucapkan & tidak terdefinisi karena tidak ada variansi \\
Konsonan $/ \mathrm{r} / \mathrm{pada}$ kata telor. dengan & data dalam data penelitian.
\end{tabular}

Tabel 6. Keberhasilan Pengucapan Konsonan /r/ Pada Kata Ember dengan Menggunakan Speech Trainer dibandingkan Antar Waktu Pengambilan Data Penelitian (Sebelum, T1, T2, T3, T4, dan T5) Menggunakan Uji Friedman Test (Uji K Berpasangan Dengan Data Kategorik)

\begin{tabular}{lccccccc}
\hline Pengucapan & Sebelum & TI & T2 & T3 & T4 & T5 & p-value \\
\hline Ember & 0 & 0 & 0 & 0 & 0 & 1 & 0,416 \\
\hline Diketahui bahwa dari & T1 sampai & ada 1 & subyek & $(25,0 \%)$ & yang berhasil \\
dengan T4 tidak ada subyek penelitian & mengucapkan Konsonan $/ \mathrm{r} /$ pada kata \\
yang berhasil mengucapkan Konsonan $/ \mathrm{r} /$ & ember. Hasil uji statistik didapatkan nilai \\
pada kata ember, dampak penggunaan & p-value = $0,416(\mathrm{p}>0,05)$ yang berarti \\
Speech Trainer dirasakan pada T5, yaitu & bahwa tidak terdapat perbedaan yang
\end{tabular}


signifikan pengucapan Konsonan /r/ pada kata ember dengan menggunakan Speech Trainer dibandingkan antar waktu pengambilan data penelitian (sebelum, T1,
T2, T3, T4, dan T5). Dengan demikian penggunaan Speech Trainer tidak efektif pada pengucapan Konsonan /r/ pada kata ember.

Tabel 7. Keberhasilan Pengucapan Konsonan /r/ Pada Kata Ekor Dengan Menggunakan Speech Trainer Dibandingkan Antar Waktu Pengambilan Data Penelitian (Sebelum, T1, T2, T3, T4, dan T5) Menggunakan Uji Friedman Test (Uji K Berpasangan Dengan Data Kategorik)

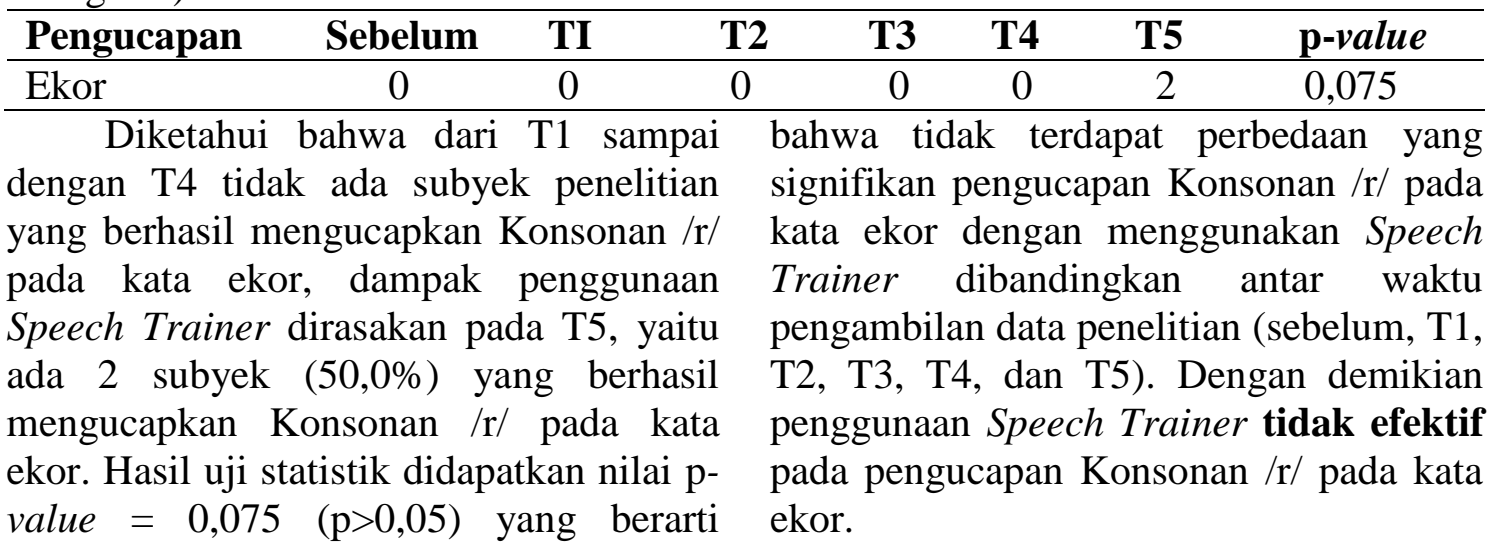

\section{PEMBAHASAN}

Penggunaan Speech Trainer tidak menunjukan adanya pengaruh pada waktu T1 sampai dengan T4, mulai ada pengaruh pada waktu T5 yaitu ditunjukan pada kata Sisir ada 3 subyek $(75,0 \%)$, telor ada 3 subyek $(75,0 \%)$, Ember ada 1 Subyek $(25,0 \%)$, dan ekor ada 2 subyek $(50,0 \%)$, sedangkan pada kata ular, dan koper tidak menunjukan adanya keberhasilan pengucapan. Keefektifan penggunaan Speech Trainer terlatak pada pengucapan konsonan /r/ pada kata sisir dan telor.

Faktor genetik (keturunan) yang diduga menyebabkan lebih dari 50\% dari semua gangguan pendengaran. Gangguan pendengaran dari cacat genetik terjadi pada saat lahir atau masa perkembangan. Kebanyakan gangguan pendengaran genetik dapat digambarkan sebagai autosomal resesif atau autosomal dominan. Lainnya, jenis yang lebih langka dari gangguan pendengaran genetik

termasuk $X$-linked (terkait dengan kromosom seks) atau pola pewarisan mitokondria.

American Speech-Language Hearing Association (2010) Faktor nongenetik yang diketahui menyebabkan gangguan pendengaran bawaan termasuk: Infeksi ibu, seperti rubella (campak Jerman), cytomegalovirus, atau virus herpes simpleks, sifat belum waktunya, berat badan lahir rendah, cedera kelahiran, racun termasuk obat-obatan dan alkohol yang dikonsumsi oleh ibu selama kehamilan. (American Speech-Language Hearing Association ,2010).

Kesalahan artikulasi selain dipengaruhi oleh faktor intelegensi juga dipengaruhi persepsi bunyi yang kurang baik, permasalahan neuro muskuler maupun sensori defisit sehingga pengucapan artikulasi menjadi salah yaitu berupa kesalahan artikulasi : subtitusi, omisi, distorsi dan adisi, sehingga bisa 
mempengaruhi kemampuan anak dalam bidang bicara, bahasa dan belajar. Semakin dini diketahui permasalahannya maka akan memberikan kemudahan bagi kita dalam penanganannya dan menghindari permasalahan baru yang mungkin timbul. Adanya kesalahan artikulasi pada beberapa siswa memudahkan upaya penanganan dan deteksi dini atau intervensi dini dalam penanganannya agar dimungkinkan dalam upaya penanganan lebih mudah dan membantu anak dalam mempermudah belajar terutama pada bahasa karena dalam komponen bahasa itu mencakup masalah bicara khususnya artikulasi serta bahasa bicara merupakan salah satu komponen kecerdasan.

Curtis EW, yang dikutip oleh $\mathrm{Ki}$ Pranindyo, artikulasi adalah kendaraan yang mengangkut makna arti dalam pikiran, ide-ide, konsep-konsep, dan sikap, dalam bentuk bunyi, kata, frase, dan kalimat. Selain mengatakan tentang praktis vokalis, Curtis menambahkan juga pentingnya ketepatan penempatan dari traktus vokalis tersebut, keselarasan dan keutuhan dari keduanya sangat menentukan dalam produksi bicara. Aturan mengenai peranan vocal tract sebagai resonator dalam membentuk posisi dikala meneria getaran dasar (fundamental frequency) dari pita suara, sehingga tercipta simbol-simbol bunyi bahasa yang dikenal dengan vokal-vokal bahasa Indonesia (a, i, u, e, o, e). Peranan vocal tract menjadi lebih rumit lagi dikala bermaksud memproduksi bunyi konsonan, vocal tract tidak hanya berfungsi sebagai resonator saja, namun berfungsi juga sebagai sumber bunyi. Dengan demikian hasil produksi bunyi konsonan dapat bersumber pada vocal tract saja dan pita suara. Dengan demikian bunyi konsonan dapat dibedakan menjadi dua yaitu konsonan bersuara dan konsonan tak bersuara.

Dalam memproduksi bunyi konsonan dibutuhkan dua hal, pertama ketepatan, kekuatan dan kecepatan gerak dari alat-alatnya (bibir, lidah, rahang dan palatum mole), kedua yaitu peranan aliran dan tekanan udara paru. Kedua, hal tersebut disebut atau dikenal dengan sistem neuro muskuler dan sistem aerodinamik.

Instrumen, aparatus, mesin dan/atau implan yang tidak mengandung obat yang digunakan untuk mencegah, mendiagnosis, menyembuhkan, terapi gangguan bahasa, wicara, suara, dan irama / kelancaran serta problem menelan. Specch Trainer alat bantu terapi untuk stimulasi auditory pada kasus disaudia.

Dalam penelitian Speech Trainer tidak menunjukan adanya pengaaruh pada waktu T1 sampai dengan T4, mulai ada pengaruh pada waktu T5 yaitu ditunjukan pada kata Sisir ada 3 subyek $(75,0 \%)$, telor ada 3 subyek $(75,0 \%)$, Ember ada 1 Subyek $(25,0 \%)$, dan ekor ada 2 subyek $(50,0 \%)$, sedangkan pada kata ular, dan koper tidak menunjukan adanya keberhasilan pengucapan. Keefektifan penggunaan Speech Trainer terletak pada pengucapan konsonan /r/ pada kata sisir dan telor.

\section{KESIMPULAN DAN SARAN}

Speech Trainer tidak menunjukan adanya pengaruh pada waktu T1 sampai dengan T4, mulai ada pengaruh pada waktu T5 yaitu ditunjukan pada kata sisir ada 3 subyek $(75,0 \%)$, telor ada 3 subyek (75,0\%), Ember ada 1 Subyek $(25,0 \%)$, dan ekor ada 2 subyek $(50,0 \%)$, sedangkan pada kata ular, dan koper tidak menunjukan adanya keberhasilan 
pengucapan. Dan keefektifan penggunaan Speech Trainer terletak pada pengucapan konsonan $/ \mathrm{r} /$ pada kata sisir dan telor pada T5 $(\mathrm{p}=0,010)$.

Saran:

Peneliti memberikan saran untuk menambah wawasan bagi terapis wicara dan praktisi pendidikan dan kesehatan anak tentang Pemakaian Alat Bantu Terapi Wicara Speech Trainer pada Kasus Disaudia karena Gangguan Pendengaran dan penggunaan alat minimalis yang manfaatnya sangat besar.

\section{DAFTAR RUJUKAN}

Curtis E Weiss Mary, E Gordon Herold, S Lilly White, 1980; Clinical Management

Articulation And Phonologic Disorder,London 1980.

Departemen Kesehatan RI, Studi Morbiditas dan Disabilitas, Laporan SKRT 2001, Badan Penelitian dan Pengembangan Kesehatan, Jakarta, 2001

Departemen Kesehatan RI, Undang Undang Nomor 36 Tahun 2009, Tentang Kesehatan.

John Palmer, 1971; Anatomy For Speech And Hearing; University Of Washington; 1971

Kementerian Kesehatan RI, Peraturan Menteri Kesehatan RI No. 24, Tentang

Penyelenggaraan Pekerjaan dan Praktik Terapis Wicara.

Kementerian Kesehatan RI No 81 Tahun 2014 Tentang Stándar Pelayanan Terapis Wicara

Mulyono Abdurrahman,1995; Pendidikan Bagi Anak Kesulitan Belajar, Jakarta 1995; FKIP IKIP

Ratlan Pardede, Reinhard Manurung, 2014, Teori dan Aplikasi Dalam
Riset bIsnis, Analisis Jalur, Path Analysis, Penerbit Rineka Cipta Jakarta, 2014

Siswoyo Haryono, 2015, Metode Sem untuk Penelitian Manajemen dengan Amos Lisrel PLS, PT, Interpesona Personalia Jakarta, 2015 